\title{
CASINOS AND ECONOMIC GROWTH: AN UPDATE
}

\author{
Douglas M. Walker \\ Department of Economics and \\ Finance, \\ College of Charleston \\ dougwalker2@gmail.com
}

\author{
John D. Jackson \\ Department of Economics \\ Auburn University \\ johndjackson2@gmail.com
}

\section{ABSTRACT}

As U.S. politicians and voters continue to grapple with the slower-thanexpected recovery from the 2007-09 recession, the legalization (or expansion) of commercial casinos has become an increasingly popular policy. Casinos are politically popular because the state government legalizes them, and can thus create a new industry which pays high taxes and may stimulate employment and economic development. Despite the fact that casinos are now widespread in the United States - there are around 1,000 commercial and tribal casinos - the empirical evidence on their economic impacts is still negligible.

In two previous studies (we have tested the relationship between statelevel casino revenues and per capita income (i.e., economic growth) to provide evidence on whether or not casinos have a positive economic impact on states' economies. We have utilized a Granger causality model modified for use with panel data. Our initial evidence, from a paper published in 1998, indicated that casinos do Granger cause economic growth. However, when we re-tested the model using up-to-date data (at the time, through 2005), we found no significant results. The casino industry has grown extensively since 2005, and although the recession of 2007-09 had a negative impact on the casino industry, the national-level revenue numbers are again climbing.

We extend our previous analyses in order to provide updated evidence on the economic growth impact of commercial casinos in the United States. Section 1 provides a more detailed background of our previous analysis and an overview of other relevant literature. Section 2 describes the data and model, and provides the results. Section 3 is a discussion and conclusion.

\section{BACKGROUND}

The 1987 U.S. Supreme Court decision in California v. Cabazon Band of Mission Indians and the 1988 federal Indian Gaming Regulatory Act paved the way for the current proliferation of casinos in the United States. The 1987 decision ruled that state governments did not have authority to regulate tribal gambling or casinos. With the 1988 legislation, the federal government designated some regulatory powers over tribal casinos to state governments. 
A key part of the legislation required that tribes be allowed to offer forms of gambling on their reservations, as long as the gambling is not explicitly banned in the state. Tribes are required to sign an agreement (a compact) with the state government before they can open a casino. In many cases, these compacts include an agreement on the part of the tribe to pay the state government a portion of the casino's revenues. ${ }^{1}$

Table 1. State commercial casino legalization and 2010 data

\begin{tabular}{|lcccccc|}
\hline \multicolumn{1}{|c}{ State } & $\begin{array}{c}\text { Year } \\
\text { Legalized }\end{array}$ & $\begin{array}{c}\text { Date } \\
\text { Casino(s) } \\
\text { Opened }\end{array}$ & $\begin{array}{c}\text { \# Casinos } \\
\text { Operating } \\
\text { in 2010 }\end{array}$ & $\begin{array}{c}\text { Commercial } \\
\text { Casino } \\
\text { Employees in } \\
\mathbf{2 0 1 0}\end{array}$ & $\begin{array}{c}\mathbf{2 0 1 0} \\
\text { Revenues } \\
\text { (\$ millions) }\end{array}$ & $\begin{array}{c}\mathbf{2 0 1 0} \\
\text { Taxes Paid } \\
\text { (\$ millions) }\end{array}$ \\
\hline Colorado & 1990 & $10 / 1991$ & 37 & 9,589 & 759 & 107 \\
\hline Illinois & 1990 & $9 / 1991$ & 9 & 6,892 & 1,374 & 466 \\
\hline Indiana & 1993 & $12 / 1995$ & 11 & 14,144 & 2,794 & 874 \\
\hline lowa & 1989 & $4 / 1991$ & 14 & 8,915 & 1,368 & 305 \\
\hline Louisiana & 1991 & $10 / 1993$ & 14 & 16,873 & 2,374 & 572 \\
\hline Michigan & 1996 & $7 / 1999$ & 3 & 8,067 & 1,378 & 311 \\
\hline Mississippi & 1990 & $8 / 1992$ & 30 & 24,707 & 2,390 & 285 \\
\hline Missouri & 1993 & $5 / 1994$ & 12 & 11,071 & 1,788 & 486 \\
\hline Nevada & 1931 & 1931 & $256^{\text {a }}$ & 175,024 & 10,405 & 835 \\
\hline New Jersey & 1976 & 1978 & 11 & 34,145 & 3,565 & 305 \\
\hline Pennsylvania & 2004 & $10 / 2007$ & 4 & 12,664 & 2,486 & 1,328 \\
\hline South Dakota & 1989 & $11 / 1989$ & 34 & 1,512 & 106 & 16 \\
\hline Totals & & & $\mathbf{4 3 5}$ & $\mathbf{3 2 3 , 6 0 3}$ & $\mathbf{3 0 , 7 8 7}$ & $\mathbf{5 , 8 9 0}$ \\
\hline
\end{tabular}

Source: American Gaming Association (2010) and Calcagno et al. (2010).

Note: ${ }^{a}$ The Nevada casino count includes only casinos with gaming revenues over $\$ 1$ million per year.

As tribal casinos began spreading, some state governments decided that the introduction of commercial casinos could be beneficial to state governments - if tribal casinos were coming anyway. After all, the state could control how many commercial casinos could be built, their sizes, and the tax rates applied to them. At the end of 2012, 464 commercial land-based or riverboat casinos, 49 racetrack casinos, and 466 tribal casinos were operating in 39 states (American Gaming Association 2013). ${ }^{2}$ Several states have

\footnotetext{
${ }^{1}$ For a detailed discussion of the development of tribal casinos see Light and Rand (2005).

${ }^{2}$ Tribal casinos are owned and operated by tribes, which are considered sovereign nations. As such, they do not publicly report casino revenues. This makes it virtually impossible to do empirical analysis of tribal casinos, and they are not included in the analysis in this paper. "Commercial casinos" are defined in this paper as any publicly or privately owned non-tribal casino that legally offers machine and table games. Racetrack casinos ("racinos") commonly offer only slot machines or video lottery terminals (VLTs), and some offer machine games that replicate casino table games.
} 
recently legalized or expanded their casinos (e.g., Kansas, Maine, Maryland, Massachusetts, Ohio), or are actively considering legalization or expansion (e.g., Kentucky, New Hampshire, New York, Texas).

Our analysis focuses on the economic impacts of land-based or riverboat commercial casinos. (We do not consider tribal casinos or racinos in our analysis.) Table 1 presents the states included in our analysis; these states had legal commercial casinos at the end of 2010. The table shows the year casinos were legalized, when they began operating in the states, and how many casinos were operating at the end of 2010. Also shown are the number of casino employees in each state, and the total revenues and taxes paid by commercial casinos to the states. ${ }^{3}$

As the table indicates, the commercial casino industry is a substantial one. Since more states are considering legalization, it must be assumed that politicians expect positive economic benefits despite casinos becoming more widespread.

\subsection{Previous studies}

Despite the expansion of the commercial casino industry, there have been relatively few empirical studies of the economic impacts of casinos. However, a few studies have examined how casinos affect labor markets (Cotti 2008), state tax revenues (Walker and Jackson 2011), housing prices (Wenz 2007), retail property values (Wiley and Walker 2011), and other casinos in the region (Condliffe 2012; Walker and Nesbit 2013). What seems to be clear from these and other studies is that the economic impacts of casinos may vary by market. In states like Nevada, it is difficult to imagine the casino industry not having a strong positive effect on the state's economy. But the impact is less clear in a state like South Dakota, where a small industry operates in a small population state.

In two previous studies on the economic growth effects of casinos, the authors used a Granger causality model modified to use panel data, in order to test for a relationship between casino revenues and state per capita income. In the first paper (1998) we used quarterly data from 1978-96, and found that casinos Granger caused per capita income. However, when we repeated the analysis in a subsequent paper (2007) using annual data from 1991-2005, we found no Granger causal relationship between casinos and per capita income. We explained these contradictory results by suggesting that perhaps there is an initial short-term positive stimulus effect from casinos, which die out over time as the casinos become an integral part of the regional economy.

\footnotetext{
${ }^{3}$ Three other states (Kansas, Maryland, and West Virginia) had casinos operating in 2010 , but they are excluded from our analysis because these states do not have enough years' data to be included in the empirical model. Aside from that, two of the states' casinos did not have table games during the full year, and in one state the casino opened in late 2010.
} 
Alternatively, as casinos have become more widespread, perhaps any positive stimulus effects they would have are competed away.

In another analysis of the effects of the casino industry rebuilding in the wake of Hurricane Katrina, we found that casinos had a statistically significant positive impact on per capita incomes, relative to the recovery experienced in non-casino states (Walker and Jackson 2008).

Given our analyses have provided contradictory answers to the question of whether casinos promote economic growth, we thought it might be a useful endeavour to re-visit the question, given five more years and one more state of data are available since our 2007 paper, and because casinos continue to be an important and controversial policy issue.

\section{MODEL, DATA, AND RESULTS}

In our two previous studies of casinos and economic growth, we posited a Granger causality model that was modified to use panel data. Here we provide a brief description of the model. ${ }^{4}$ Granger causality analysis is straightforward. A variable, $X_{t}$, Granger causes another variable, $Y_{t}$, if, with information on all factors affecting both $X_{t}$ and $Y_{t}$, the current value of $Y_{t}$ can be predicted more accurately by using past values of $X_{t}$ than by not using them. The same can be said to test whether $Y_{t}$ Granger causes $X_{t}$. In this paper we use the Granger causality approach to test the relationship between per capita personal income (PI) and casino revenues (CR), for state $i$ and year $t$, as shown in equations (1) and (2):

$$
\begin{aligned}
& C R_{i, t}=\sum \omega_{j} C R_{i, t-j}+\sum \theta_{j} P I_{i, t-j}+\varepsilon_{i, t} \\
& P I_{i, t}=\sum \vartheta_{j} P I_{i, t-j}+\sum \rho_{j} C R_{i, t-j}+\varepsilon_{i, t}
\end{aligned}
$$

The analysis has four possible outcomes:

I. $\quad P I$ Granger causes $C R$ if, for (1), $\mathrm{H}_{0}: \theta_{j}=0$, for all $j$, can be rejected;

II. $\quad C R$ Granger causes $P I$ if, for (2), $\mathrm{H}_{0}: \rho_{j}=0$, for all $j$, can be rejected;

III. bi-directional Granger causality ('feedback'), if the null hypotheses from both (i) and (ii) are rejected; or

IV. no Granger causal relationship between $C R$ and $P I$, if neither (i) nor (ii) applies.

It is important to emphasize that Granger causality only suggests that if one variable helps to predict another, then the first variable is somehow

\footnotetext{
${ }^{4}$ For a complete description of the methodology, see Walker and Jackson (1998).
} 
contributing to the process of the second variable. Thus, Granger causality does not prove a "causal" relationship in the traditional sense of the word. Nevertheless, it does provide useful statistical information about the relationship between the variables.

We are interested in testing for a Granger causality relationship between state-level casino revenues and per capita personal income. In our previous paper we describe a mechanism for applying Granger causality analysis to panel data. First, we filter the data and test the residuals for stationarity. The filtering equation regresses each dependent variable on a time trend, a set of state dummy variables to account for state-specific effects, and a series of interaction terms for the trend and each state dummy. An additional variable in the casino revenue equation is a dummy indicating no casino revenue (for state $i$ during year $t$ ). The residuals from these filtering equations are tested for stationarity using a Phillips-Perron test, which is robust with respect to the number of lagged difference variables included in the test equation. ${ }^{5}$ The stationary residuals from the filtering process represent the $P I_{i, t}$ and $C R_{i, t}$ variables from equations (1) and (2) that are used in the Granger causality tests.

Next, we must determine what autoregressive process generates each filtered series. In our previous analyses we have done this by regressing each residual series on its own past values, adding lag periods until the residuals from that model are white noise, according to Box-Pierce $Q$-statistics. Elsewhere in the literature, it has been suggested that a 4-period lag structure is traditionally used in Granger causality applications (Thornton and Batten 1985). We test two- through five-year lag equations (as shown in the results, below), to account for different opinions on how many lag periods should be included.

The final step is to run the Granger causality model.

Our empirical model includes the 12 states shown in Table 1 . We collected state-level commercial casino revenue and personal per capita income data, for 1990-2010. Thus, we have 21 years' data on 12 states, or 252 observations. The data were adjusted for inflation using the Consumer Price Index (CPI). ${ }^{6}$

\footnotetext{
${ }^{5}$ The filtering process is important for at least three reasons. First, it should eliminate any concern about the order in which the states' data are stacked for the analysis, especially since the residuals are stationary. Second, removing trend effects should minimize the likelihood that any results are attributable to a common trend between the casino revenue and personal income variables. Finally, since the residuals are stationary, it ensures that any innovation in the series, whether state-specific or attributable to another time-independent factor, is of temporary duration.

${ }^{6}$ Casino revenue data are from the respective states' casino regulatory agencies. Personal per capita income data are from the Bureau of Economic Analysis. CPI data are from the Bureau of Labor Statistics.
} 
As noted above, we run the Granger causality model using different lagstructures, from 2-year through 5-year. The results are shown in Table 2. ${ }^{7}$ In each model, we find that casino revenues (CR) Granger cause personal per capita income (i.e., economic growth; PI), at either the $5 \%$ or $1 \%$ level. In none of the models did we find that economic growth (PI) Granger causes casino revenues $(\mathrm{CR})$.

Table 2. Granger causality results

\begin{tabular}{|lllll|}
\hline Null Hypothesis $^{\text {a }}$ & $\begin{array}{l}\text { Lag } \\
\text { Periods }\end{array}$ & Obs. & F-statistic $^{\mathbf{b}}$ & Probability \\
\hline PI does not Granger cause CR & 2 & 228 & 1.808 & 0.166 \\
CR does not Granger cause PI & & & 4.784 & 0.009 \\
\hline PI does not Granger cause CR & 3 & 216 & 1.283 & 0.281 \\
CR does not Granger cause PI & & & 3.339 & 0.020 \\
\hline PI does not Granger cause CR & 4 & 204 & 1.231 & 0.299 \\
CR does not Granger cause PI & & & 3.009 & 0.019 \\
\hline PI does not Granger cause CR & 5 & 192 & 1.369 & 0.238 \\
CR does not Granger cause PI & & & 3.438 & 0.005 \\
\hline
\end{tabular}

Notes: The variables tested are the residuals from the filtering process. PI=real personal per capita income; $\mathrm{CR}=$ real casino revenue.

a The hypothesis "PI does not Granger cause CR" relates to equation (1). The hypothesis for "CR does not Granger cause PI" relates to equation (2).

${ }^{\mathrm{b}}$ The $F$-test represents a joint significance test on the null hypotheses described in note a.

\section{DISCUSSION AND CONCLUSION}

Our results based on data from 1990-2010, on the 12 land-based and riverboat casino states, indicate that casinos Granger cause changes in per capita personal income. The results are surprisingly robust to the number of lag periods tested, which seems to indicate a clear relationship between casinos and economic growth.

These results are consistent with other evidence on the positive economic impacts of casinos, such as Cotti's (2008) analysis showing positive countylevel employment and wage effects from casinos. Comparing these results with our own previous results, we note that these results are similar to the 1998 study, which analysed data in most casino states from 1991-96. ${ }^{8}$ The results here also support our findings on the economic growth effects of casinos in the wake of Hurricane Katrina. Of course, these newest results stand in contrast to our 2007 study, in which we found no Granger causal relationship between casinos and state-level economic growth, using data from 1991-2005.

One possible interpretation of these different results is that casinos have a counter-cyclical effect on the state economy. Compared to the sample period

\footnotetext{
${ }^{7}$ The results table was presented and summarized in Walker $(2013,55)$.

${ }^{8}$ The 2007 study also included data on New Jersey going back to 1978, and Nevada going back to 1985 .
} 
from the 2007 paper (1991-2005), the sample periods from the current study (1990-2010) and the 1998 study (1991-96) include more periods that were recessionary. In particular, $8.9 \%$ of the sample periods in the 2007 study were during a recession, while approximately $13 \%$ of the sample periods in the 1998 study and the current study were recessionary. Perhaps the casinos have a counter-cyclical effect on the state's economy. If casinos are somewhat resistant to recessions, then they may help offset or stabilize economic downturns, at least in their local economies. If this was occurring, then it would help explain why we found a positive Granger causality result in the 1997 and current study, but not the 2007 study. The results of the Katrina study also support this hypothesis. ${ }^{9}$

Few other empirical studies on the economic impacts of casinos have been published. As one of the few studies to examine the issue, we believe this updated analysis makes an interesting contribution to the literature because it shows that the casino industry is important to state economies. The industry has obvious political importance too, as shown by recent interest in legalizing casinos in new states. Our results support the casino industry's contention, as well as previous evidence in the literature, that the casino industry does have a positive economic effect on a host-state's economy.

\section{REFERENCES}

American Gaming Association. 2010. State of the states, 2010: The AGA survey of casino entertainment. Washington, DC: Author.

American Gaming Association. 2013. 2013 State of the States. Washington, DC: Author.

Calcagno, PT, DM Walker, and JD Jackson. 2010. Determinants of the probability and timing of commercial casino legalization in the United States. Public Choice 142:69-90.

Condliffe, S. 2012. Pennsylvania casinos' cannibalization of regional gambling revenues. UNLV Gaming Research \& Review Journal 16 (1):45-58.

Cotti, CD. 2008. The effect of casinos on local labor markets: A county level analysis. Journal of Gambling Business and Economics 2 (2):17-41.

Light, S, and K Rand. 2005. Indian gaming \& tribal sovereignty: The casino compromise. Lawrence, KS: University Press of Kansas.

Skinner, SJ, RB Ekelund, and JD Jackson. 2009. Art museum attendance, public funding, and the business cycle. American Journal of Economics and Sociology 68 (2):491-516.

Thornton, DL, and DS Batten. 1985. Lag-length selection and tests of Granger causality between money and income. Journal of Money, Credit, and Banking 17 (2):164-178.

Walker, DM. 2013. Casinonomics: The Socioeconomic Impacts of the Casino Industry. New York, NY: Springer.

\footnotetext{
${ }^{9}$ Other studies have found evidence indicating that entertainment industries are "recession proof." For example, Skinner et al. (2009) find museum attendance to be counter-cyclical.
} 
Walker, DM, and JD Jackson. 1998. New goods and economic growth: Evidence from legalized gambling. Review of Regional Studies 28 (2):47-69.

Walker, DM, and JD Jackson. 2007. Do casinos cause economic growth? American Journal of Economics and Sociology 66 (3):593-607.

Walker, DM, and JD Jackson. 2008. Market-based "disaster relief": Katrina and the casino industry. International Journal of Social Economics 35 (7):521-530.

Walker, DM, and JD Jackson. 2011. The effect of legalized gambling on state government revenue. Contemporary Economic Policy 29 (1):101-114.

Walker, DM, and TM Nesbit. 2013. Casino revenue sensitivity to competing casinos: A spatial analysis of Missouri. Growth and Change.

Wenz, M. 2007. The impact of casino gambling on housing markets: A hedonic approach. The Journal of Gambling Business and Economics 1:101-120.

Wiley, JA, and DM Walker. 2011. Casino revenues and retail property values: The Detroit case. Journal of Real Estate Finance and Economics 42:99-114. 